\title{
Laboratory Methods for the Diagnosis of Hereditary Amyloidoses
}

\author{
S. Michelle Shiller, Ahmet Dogan and W. Edward Highsmith, Jr. \\ Department of Laboratory Medicine and Pathology, Mayo Clinic College of Medicine, \\ Rochester, Minnesota \\ United States of America
}

\section{Introduction}

The majority of systemic amyloid disorders are acquired in nature and are most often secondary to plasma cell dyscrasias (AL amyloid), age-related accumulation of transthyretin (senile ATTR amyloid) or chronic inflammation (AA amyloid). A smaller, though significant, fraction of cases are due to inherited mutations in one of several amyloidogenic proteins. As described elsewhere in this volume, amyloid consists of fibrils composed of stacked proteins which have adopted a beta pleated sheet conformation. The mechanism by which a protein which has substantial alpha helical character refolds into a configuration with it's primarily beta pleated sheet is unclear and is the subject of much ongoing research. It is clear, however, that specific amino acid substitutions in a small number of circulating proteins can accelerate or facilitate this process.

All of the hereditary amyloidoses (also known as familial or systemic amyloidoses) are inherited in an autosomal dominant manner, as is the case for other "gain of function" mutations in disorders such as Huntington disease, myotonic dystrophy, or the spinocerebellar ataxias. The dominant inheritance of the familial amyloidoses has implications for family members of an affected individual. First, careful attention to the family history will often reveal symptoms in one parent, which may or may not have come to medical attention. However, even in the setting of a thorough family history, hereditary amyloidosis can be missed and attributed to more common diseases. It is important to understand that siblings and children of an affected individual have a 1 in 2 chance of being affected themselves. Thus, after the identification of an amyloidogenic mutation in an individual, it is important to offer testing for at-risk family members so that appropriate monitoring can be carried out for mutation positive family members.

The hereditary amyloidoses involve deposition of amyloid in a variety of tissues. Typically, there is a proclivity for the vascular tree, particularly the microvasculature, and it can be a cause of cerebral hemorrhage. The kidneys and the heart are the most commonly involved organs. However, virtually any organ can become involved, with liver, spleen, thyroid, larynx, gastric wall, and salivary glands all described. Further, amyloid deposition can also occur in the soft tissue adjacent to the salivary gland, tracheobronchial tree, the tongue, and in the skin.. On physical examination this diverse distribution manifests with a similar broad spectrum of features including macroglossia, peripheral edema, peripheral neuropathy, hypertension, 
papular rash, and waxy papules. Patients may demonstrate congestive heart failure as part of the restrictive cardiomyopathy conferred due to the amyloid deposition within cardiac muscle. Additionally, gastric dysmotility occurs, and cerebral hemorrhage is documented, as previously mentioned.

Clinically, it may be difficult to distinguish amyloidosis that is secondary to overproduction of immunoglobulin light chains (AL amyloid), age-related ATTR amyloidosis or serum amyloid A (AA amyloid) from an amyloidosis that is hereditary in nature. As the treatment for the underlying cause of amyloidosis is drastically different for the different etiologies, it is critical that the amyloid be properly classified. Therapy for plasma cell disease can include chemotherapy and/or bone marrow transplant, and the therapy for AA amyloid involves addressing the underling cause of inflammation, while the curative treatment for two varieties of familial amyloidosis, including the most common form due to mutant transthyretin (ATTR amyloid) is liver transplant.

To make a diagnosis, including identification of the protein being deposited as amyloid fibrils, it is typically necessary to obtain biopsy material from an affected organ or site. Most often, biopsies are obtained from either the bone marrow, subcutaneous fat (often of the abdomen), or the rectum. Following tissue acquisition, a variety of methods are used in identifying and characterizing amyloid protein. These include Congo Red staining, immunoperoxidase staining of histological tissue, mass spectrometry and genetic evaluation in cases of familial disease.

While the majority of systemic amyloidosis is due to transthyretin (TTR) mutations, identification of other genes involved in conferring aberrant protein folding with subsequent amyloid deposition have been identified. These additional genes have been documented in a substantially smaller number of individuals than TTR mutations and include ApoA1, ApoA2, gelsolin, lysozyme, and fibrinogen alpha (FGA). By and large, the most common symptom of these genetic variants is nephropathy. However, the gelsolin variant of disease does not involve the kidneys, rather it displays a predisposition for cranial nerve tissue, lattice corneal dystrophy, and cutis laxa of the facial skin. As gelsolin amyloidosis was originally identified in a large Finnish family, and is more common, but not limited to individuals of Finnish descent, it is often referred to as Finnish amyloidosis.

The differential diagnosis of systemic amyloidosis includes light chain disease, Sjögren's syndrome, rheumatoid arthritis, other inflammatory conditions, $\beta 2$-microglobulinemia, and Familial Mediterranean Fever, as well as other similar conditions. A discussion of a thorough diagnostic evaluation for these conditions is beyond the scope of this chapter. However, a few key laboratory tests can expedite the process: serum protein electrophoresis (assists in the diagnosis of light chain disease or $\beta 2$-microglobulinemia), the presence of antinuclear antibody and SSBLa>SSBRo by immunofluoresence for Sjögren's syndrome. The presence of rheumatoid factor points towards Rheumatoid Arthritis. Detection of serum amyloid A in amyloid deposits by immunohistochemistry elicits a definitive diagnosis of AA amyloid, or amyloid deposition of an inflammatory origin.

With respect to AL amyloidosis, while serum protein electrophoresis is the classical method of working up this diagnosis, ruling out hereditary amyloidosis through DNA interrogation is pivotal. Studies have demonstrated that individuals with hereditary amyloidosis may also demonstrate monoclonal immunoglobulins on serum protein electrophoresis in as many as $24 \%$ of patients. In the study by Lachmann et al., all of the patients had less than $0.2 \mathrm{~g} / \mathrm{dL}$ of immunoglobulins in the serum, and none of the 
patients had kappa or lambda free light chains by urine protein electrophoresis. Comenzo et al. had similar findings, with six percent of patients with a hereditary amyloidosis presenting definitive monoclonal gammopathies in a subject population of similar size. The differences between these two studies is that the patients with monoclonal gammopathy in the Lachmann et al. study demonstrated mutations in a variety of genes for hereditary amyloidosis, whereas in the Comenzo et al. study, all patients had TTR mutations. In the absence of DNA analysis, these patients with hereditary amyloidosis masquerading with a monoclonal gammopathy would be misdiagnosed, and the improper clinical management could be implemented.

\section{Methods used for the evaluation of tissue amyloid}

\subsection{Congo red staining}

The gold standard for the detection of the presence of amyloid is Congo Red staining (Figure 1). A paper by Cooper compared Congo Red staining against other techniques to detect amyloid at the time, and his findings demonstrated that the green birefringence demonstrated under polarized light was completely specific for the presence of amyloid. A positive Congo Red stain on a biopsy or fat aspirate does not give the specific precursor protein causing the amyloid deposition. It does, however, define the presence of amyloid, setting the stage for further diagnostic evaluation.

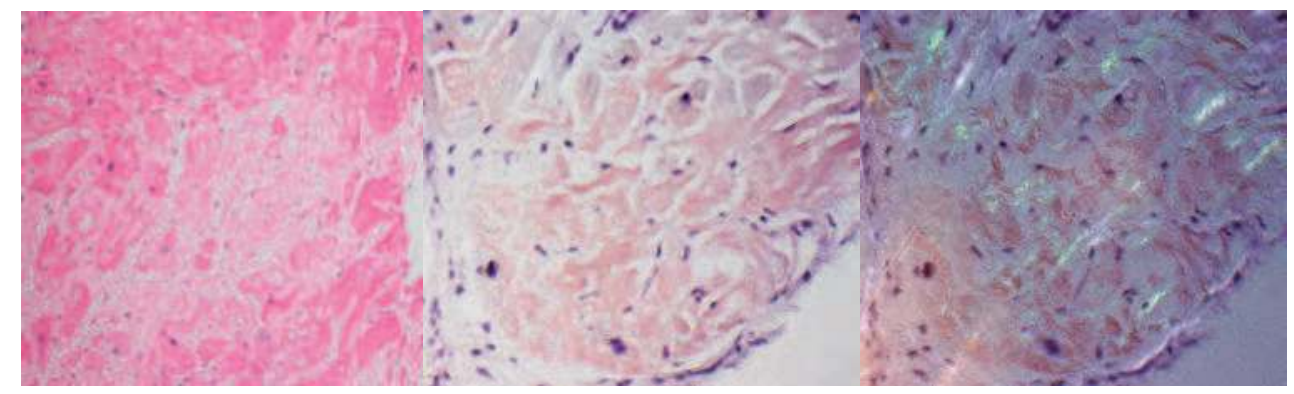

Fig. 1. Cardiac biopsy from a patient with TTR amyloidosis by hematoxylin and eosin (left), Congo Red (middle), Congo Red under polarized light with apple green birefringence (right). (Courtesy of Ahmet Dogan, MD, PhD; Mayo Clinic, Rochester, $\mathrm{MN})$.

\subsection{Immunohistochemistry}

Immunohistochemistry (IHC) has been in use for many years to identify the specific protein involved in amyloid deposits identified by Congo red staining. In principle, IHC can differentiate the most common types of amyloid, light chain, serum amyloid $\mathrm{A}$, and transthyretin (Figure 2). However, it is the authors' experience that, with the exception of serum amyloid $\mathrm{A}$, the results can be equivocal and difficult to interpret. One of the 
problems is that the epitopes that specific antisera recognize can be partially or even completely buried in the insoluble amyloid fibril. There is a lack of high affinity antibodies specific for amyloidogenic proteins in the beta pleated sheet conformation. Further, a trained eye for interpretation of the results is required, with the ability to discern a poor staining pattern (such as that seen with serum leakage into amyloid plaques), and to recognize nonspecific or non-contributory background staining (low specificity and sensitivity). In addition, the adverse effects of changing protein structure by crosslinking due to formalin fixation limits the utility of immunohistochemistry in detecting amyloid deposition (demonstration of this phenomena thus far has been limited to TTR). If TTR is identified, IHC is unable to distinguish between a mutant TTR protein in a case of familial amyloid and a wild-type protein in case of senile amyloid (see the discussion of TTR and ApoA2 amyloid below). Finally, typical IHC panels consisting of antibodies to kappa and lambda light chains, serum amyloid A, and TTR, cannot identify the presence of less common amyloids consisting of lysozyme, gelsolin, fibrinogen alpha, or apolipoproteins 1 , or 2 .

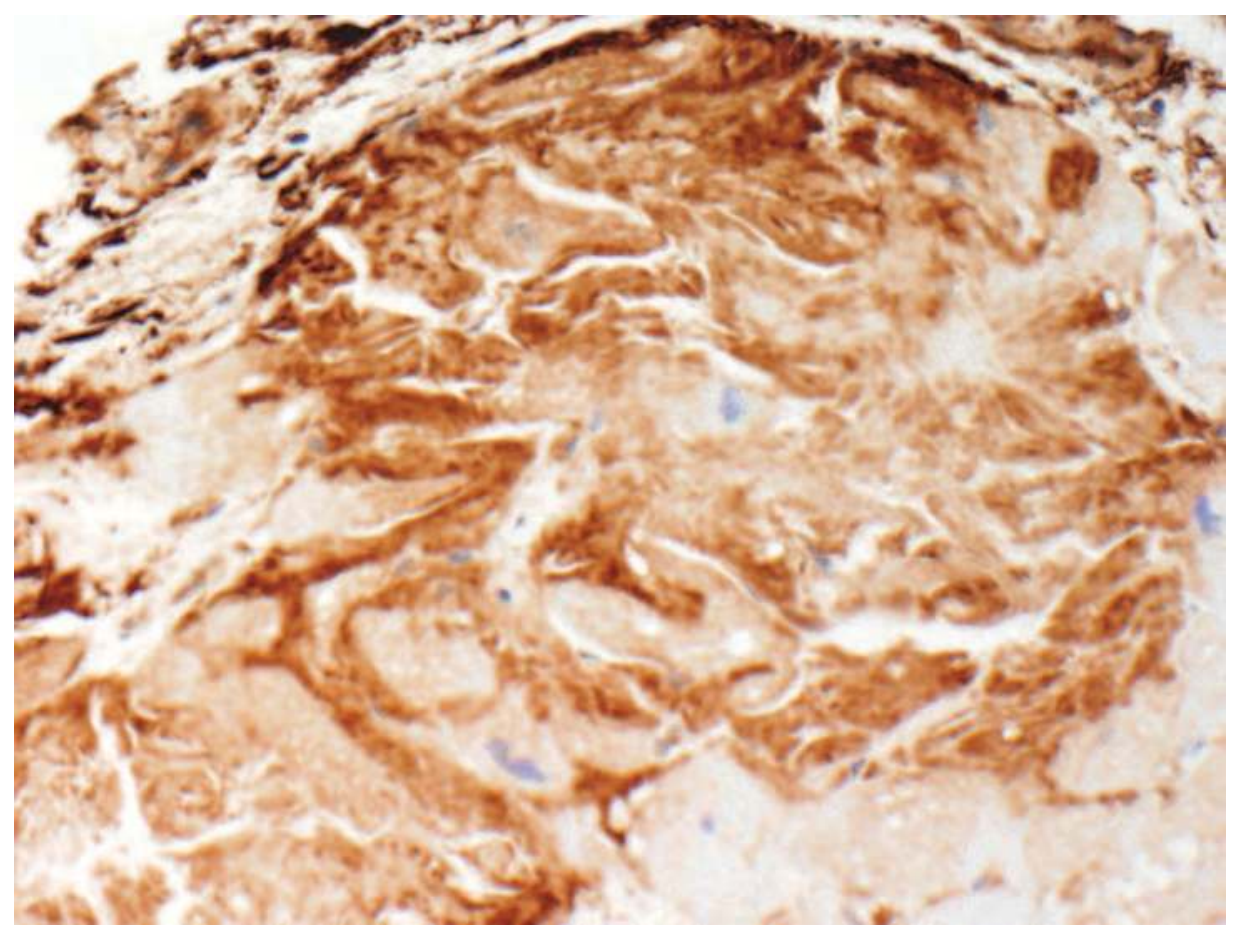

Fig. 2. Cardiac biopsy with TTR amyloid, positive for TTR by immunohistochemistry (photograph courtesy of Ahmet Dogan, MD, PhD; Mayo Clinic, Rochester, MN). 


\subsection{Electron microscopy}

Ultrastructural examination (electron microscopy) of amyloid is not a common method of identifying this pathology. However, on ultrastructural examination, amyloid has a fibrillar pattern (Figure 3). Of note, there are several other fibrillary diseases of the kidney such as fibrillary glomerulonephritis and immunotactoid glomerulopathy, both of which are completely different entities than hereditary amyloid. Thus, fibrillary glomerular deposits by electron microscopy are non-specific, and additional studies are warranted to determine their etiology.

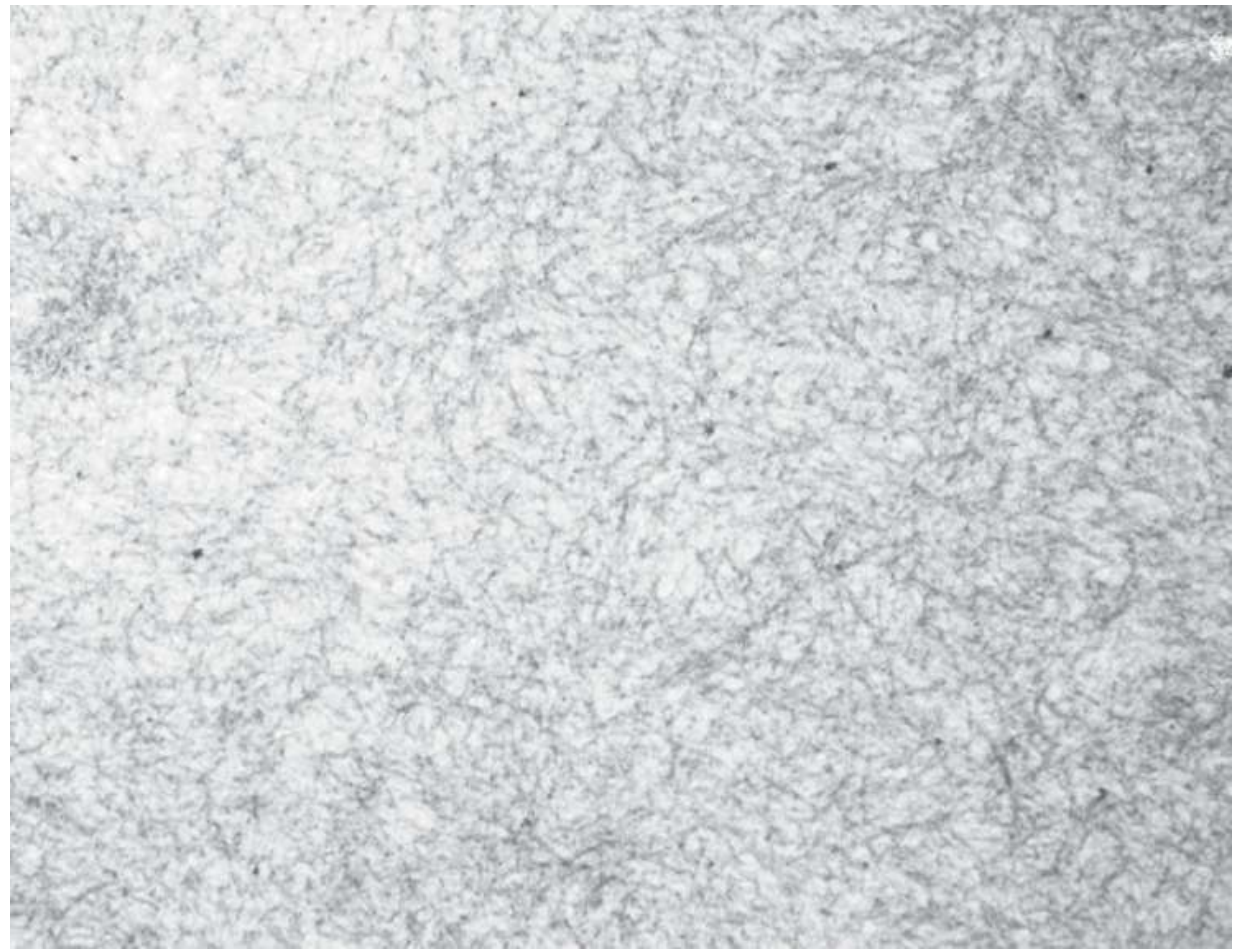

Fig. 3. Electron microscopy of amyloid fibrils measuring 6-10 nanometers in a patient with cardiac amyloidosis (photograph courtesy of Ahmet Dogan, MD, PhD; Mayo Clinic, Rochester, MN).

\subsection{Mass spectrometry}

More recently with new technological developments, mass spectrometry (MS) based proteomic methodologies have been applied to subtype amyloidosis. Initial studies using MS, similar to amino acid sequencing approaches, required large quantities of fresh or frozen tissue with a heavy amyloid load. However, in recent years, the sensitivity of MS based technologies has significantly improved and methods to extract proteins and peptides from small amounts of clinical biopsy specimens have been developed. This has led to development of a highly sensitive and specific clinical test for typing of amyloid deposits in paraffin embedded tissues. The approach incorporates laser capture microdissection (LCM) 
of amyloid plaques up front which dramatically increases the amount of proportion signal coming from the amyloidogenic protein compared to the signal coming from the background tissue (Figure 4).

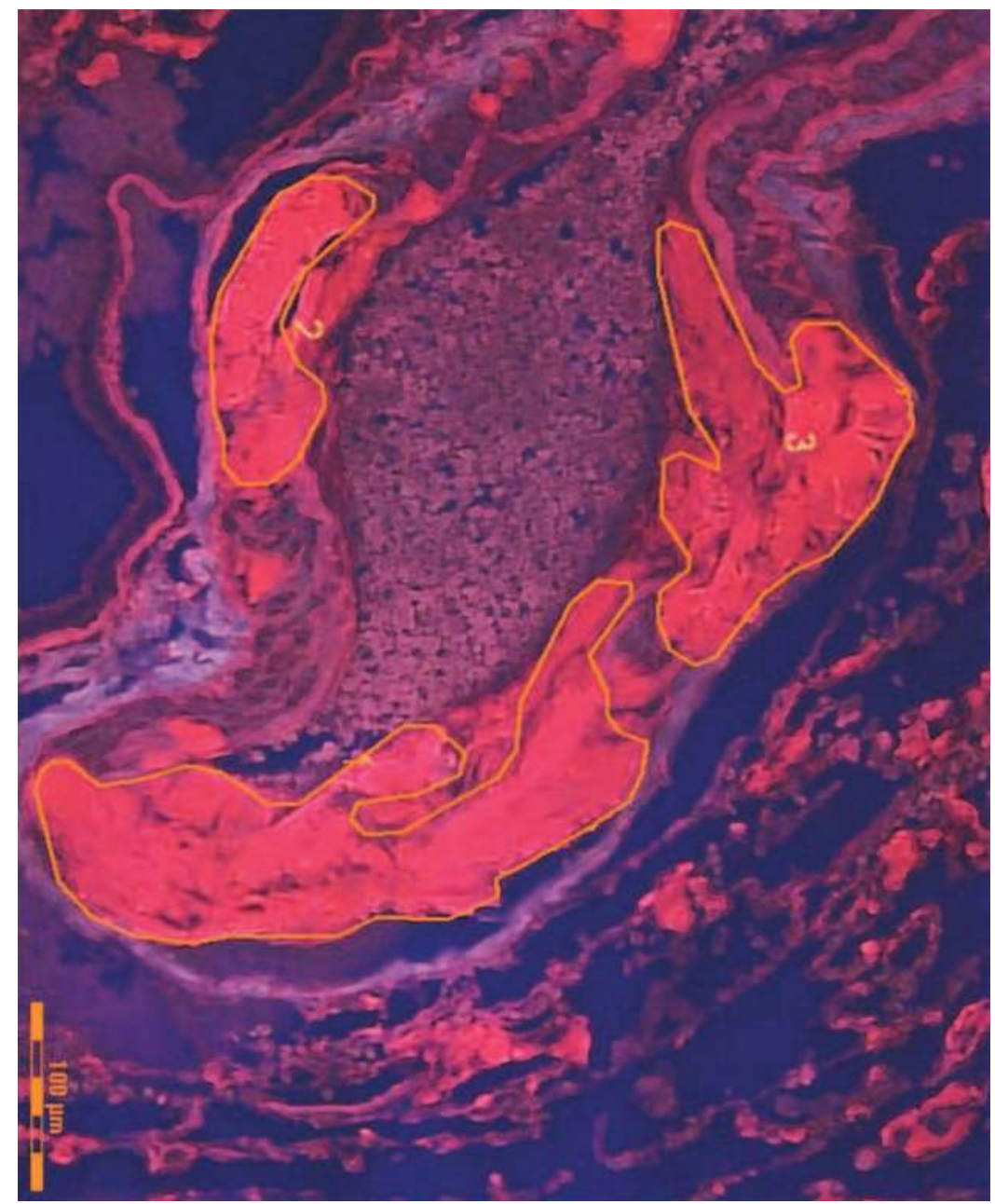

Fig. 4. AA amyloidosis showing predominantly vascular deposition with Congo red staining. For mass spectrometry based proteomic analysis, the areas circled by yellow lines are microdissected with laser and the microdissected fragments are collected in the tube cap ready for protein extraction and digestion into peptides suitable for tandem mass spectrometry (courtesy of Ahmet Dogan, MD, PhD; Mayo Clinic, Rochester, MN).

Once the amyloid plaques are captured, they are fragmented by heating and sonication to reverse crosslinking caused by formalin fixation, followed by digestion into peptide fragments by trypsin. Trypsin specifically cleaves the proteins following lysine and arginine residues and generates a peptide "soup." For each protein a specific and reproducible set of peptides is 
generated. The peptide solution is fractionated by high performance liquid chromatography and peptides are introduced into the mass spectrometer by a process called electrospray ionization (ESI). ESI provides the interface between the liquid environment of the HPLC and the high vacuum environment of the MS. It also adds charges to the peptides so that they can be detected and manipulated by MS. After ESI, the peptides are analyzed by tandem MS/MS. The first MS detects mass/charge ratio $(\mathrm{m} / \mathrm{z})$ of each peptide (precursor ion) as they are focused in the mass spectrometer. Based on relative abundance and other preset criteria, a subset of the charged peptides are selected for collision-induced dissociation. This leads to fragmentation of the peptides into smaller charged particles (product ions). Mass/charge ratio of these fragments is captured by the second MS (tandem mass spectrometry, MS/MS). This raw MS data is then interrogated by bio-informatic algorithms which match the fragmentation pattern of each peptide to one of the theoretical tryptic peptides present in human proteome. In this way, amino acid sequence of each peptide analyzed by MS/MS is predicted with high specificity. Proteins are identified and displayed in order of relative abundance based on the total number of peptide spectra identified for each protein (Figure 5). Using this approach amyloid deposits can be subtyped by very high sensitivity and specificity $(100 \%$ for both in the published validation set) (Vrana et al., 2009).

\begin{tabular}{|c|c|c|c|c|c|c|}
\hline$*$ & $\begin{array}{l}\begin{array}{l}\text { Probability Legend: } \\
\text { over } 95 \% \\
80 \% \text { to } 94 \% \\
50 \% \text { to } 79 \% \\
20 \% \text { to } 49 \% \\
0 \% \text { to } 19 \% \\
\text { Bio View: } \\
\text { Identified Proteins (463) }\end{array} \\
\end{array}$ & 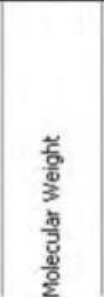 & 1 & 2 & 3 & 4 \\
\hline 1 & Serum albumin OS=Homo sapi... ALBU_HUMAN & $69 \mathrm{KDa}$ & 58 & 79. & 59 & 52 \\
\hline 2 & -Transthyretin OS=Homo sapie...TTHY_HUMAN & $16 \mathrm{KDa}$ & 26 & 26 & 26 & 25 \\
\hline 3 & Apolipoprotein E OS=Homo sa....APOE_HUMAN & $36 \mathrm{KDa}$ & 30 & 31 & 25 & 19 \\
\hline 4 & Serum amyloid P-component ... SAMP_HUMAN & $25 \mathrm{KDa}$ & 33 & 27 & 25 & 19 \\
\hline 5 & Apolipoprotein A-IV OS=Homo...APOA4_HUMAN & $45 \mathrm{Ka}$ & 24 & 28 & 17 & 18 \\
\hline 6 & Collagen alpha-1(I) chain OS... CO1A1_HUMAN & $139 \mathrm{KDa}$ & 14 & 16 & 24 & 22 \\
\hline 7 & Vitronectin OS=Homo sapiens... VTNC_HUMAN & $54 \mathrm{Ka}$ & 22 & 17 & 13 & 11 \\
\hline 8 & ITR Val30Met GTG $\rightarrow$ ATG "A...TTHY_Val30... & $1 \mathrm{kDa}$ & 19 & 13 & 13 & 12 \\
\hline 9 & Complement C3 OS=Homo sap...CO3_HUMAN & $187 \mathrm{kDa}$ & 15 & 15 & 8 & 6 \\
\hline 10 & Collagen alpha-2(I) chain OS... CO1A2_HUMAN & $129 \mathrm{kDa}$ & 9 & 13 & 18 & 14 \\
\hline 11 & Complement factor $\mathrm{H}$-related ... FHR 1_HUMAN & $38 \mathrm{KDa}$ & 12 & 13 & 8 & 7 \\
\hline 12 & Ig gamma-1 chain C region $0 . .$. IGHG1_HUMAN & $36 \mathrm{KDa}$ & 9 & 7 & 9 & 8. \\
\hline 13 & Fibulin-1 OS=Homo sapiens G... FBLN1_HUMAN & $77 \mathrm{Ka}$ & 8 & 10 & 9 & 6 \\
\hline 14 & Vimentin OS=Homo sapiens G... VIME_HUMAN & $54 \mathrm{Ka}$ & 6 & 12 & 6 & 7 \\
\hline 15 & Collagen alpha-3(VI) chain OS...CO6A3_HUMAN & $344 \mathrm{kDa}$ & 5 & 11 & 5 & 3 \\
\hline 16 & Ig kappa chain C region OS $=\ldots$ IGKC_HUMAN & $12 \mathrm{Ka}$ & 5 & 6 & 5 & 7 \\
\hline 17 & Katanin p60 ATPase-containin....KATL1_HUMAN & $55 \mathrm{Ka}$ & 2 & 3 & 4. & \\
\hline 18 & Trypsin-3 OS=Homo sapiens ... TRY3_HUMAN & $33 \mathrm{KDa}$ & 5 & 5 & 4 & 5 \\
\hline 19 & Midkine OS=Homo sapiens GN... MK_HUMAN & $16 \mathrm{KDa}$ & 6 & 5 & 2 & 1 \\
\hline 20 & Collagen alpha-1(III) chain $0 . . . C O 3 A 1$ HUMAN & $139 \mathrm{kDa}$ & 2 & 4. & 2 & 4 \\
\hline
\end{tabular}

Fig. 5. Mass spectrometry based proteomic analysis of hereditary amyloidosis. Transthyretin (red arrow) is the most dominant amyloidogenic protein in all four microdissections studied. Gene sequencing confirmed Val50Met in this case. (courtesy of Ahmet Dogan, MD, PhD; Mayo Clinic, Rochester, MN). 


\section{Genetic evaluation of familial amyloidosis}

\subsection{Genetic evaluation}

Gene sequencing is the gold standard to detect aberrations such as substitutions, and small deletions and insertions at the nucleotide level. Sequencing is particularly useful when heterogeneity occurs in a disease, as with amyloidosis. The familial amyloidoses display both genetic heterogeneity (multiple genes being involved in a disease) and allelic heterogeneity (multiple mutations in the sample gene being able to cause the disease).

The first step in any DNA sequencing is the extraction, or purification, of DNA, typically from a peripheral blood sample. Many platforms are available for DNA extraction, the authors use the MagNaPure ${ }^{\circledR}$ LC (Roche Diagnostics). Following DNA extraction, the samples are prepared for PCR with primers specific to the gene of interest, and the standard PCR constituents (Taq polymerase, buffer, magnesium chloride and PCR-grade water). The authors perform a gel electrophoresis next to confirm the PCR reaction prior to proceeding with the sequencing assay. Next, the PCR product is treated, or "cleaned" to remove unincorporated primers and nucleotides. Again, there are multiple ways that this can be accomplished. The authors utilize shrimp alkaline phosphatase (to convert unincorporated deoxynucleotide triphosphates ( $\left.\mathrm{dNTP}^{\prime} \mathrm{s}\right)$ into dephosphorylated products that will not interfere with the downstream sequencing reaction) and exonuclease (to digest unextended PCR primers into nucleotides to prevent unwanted extension during the sequencing reaction). The cleaned PCR product is next combined with a mixture of fluorescently labeled di-deoxynucleotide triphosphates and dNTP's (ex: BigDye ${ }^{\circledR}$ terminators [Applied Biosystems]), sequencing buffer, PCR grade water, and a thermostabile DNA polymerase. After carrying out the sequencing reaction by thermal cycling and another purification step, this time removing unincorporated fluorescent material, the sample is analyzed by capillary electrophoresis. There are multiple software programs commercially available for base calling, alignments, and mutation detection. The authors use Mutation Surveyor ${ }^{\circledR}$ (Soft Genetics) (Figure 6).

\section{Genes involved in hereditary amyloidosis}

\subsection{Notes on nomenclature}

The Human Genome Variation Society (HGVS) has proposed standard nomenclature for variation both at the nucleotide and the protein level (www.hgvs.org/mutnomen/). In this chapter, all mutations and variants will be discussed referring to protein sequence, or amino acid changes. The HGVS recommends that proteins be numbered starting with the initiator methionine as amino acid number one. Older literature often uses a different convention. Previously, the standard nomenclature was to number the first amino acid of the mature, processed protein as amino acid number one. For secreted proteins (such as those involved in familial amyloidoses), this numbering system neglected the signal peptides and propeptides that are cleaved from the amino terminus after translation as the protein is being processed by the cell for secretion. All of the amino acid changes discussed here will use the HGVS standard nomenclature.

For example, the signal peptide of the TTR protein is 20 amino acids in length. One mutation seen in TTR amyloid is Cys30Arg (new nomenclature). Using historical nomenclature, the mutation is termed Cys10Arg (subtract 20 amino acids that account for the signal peptide in 


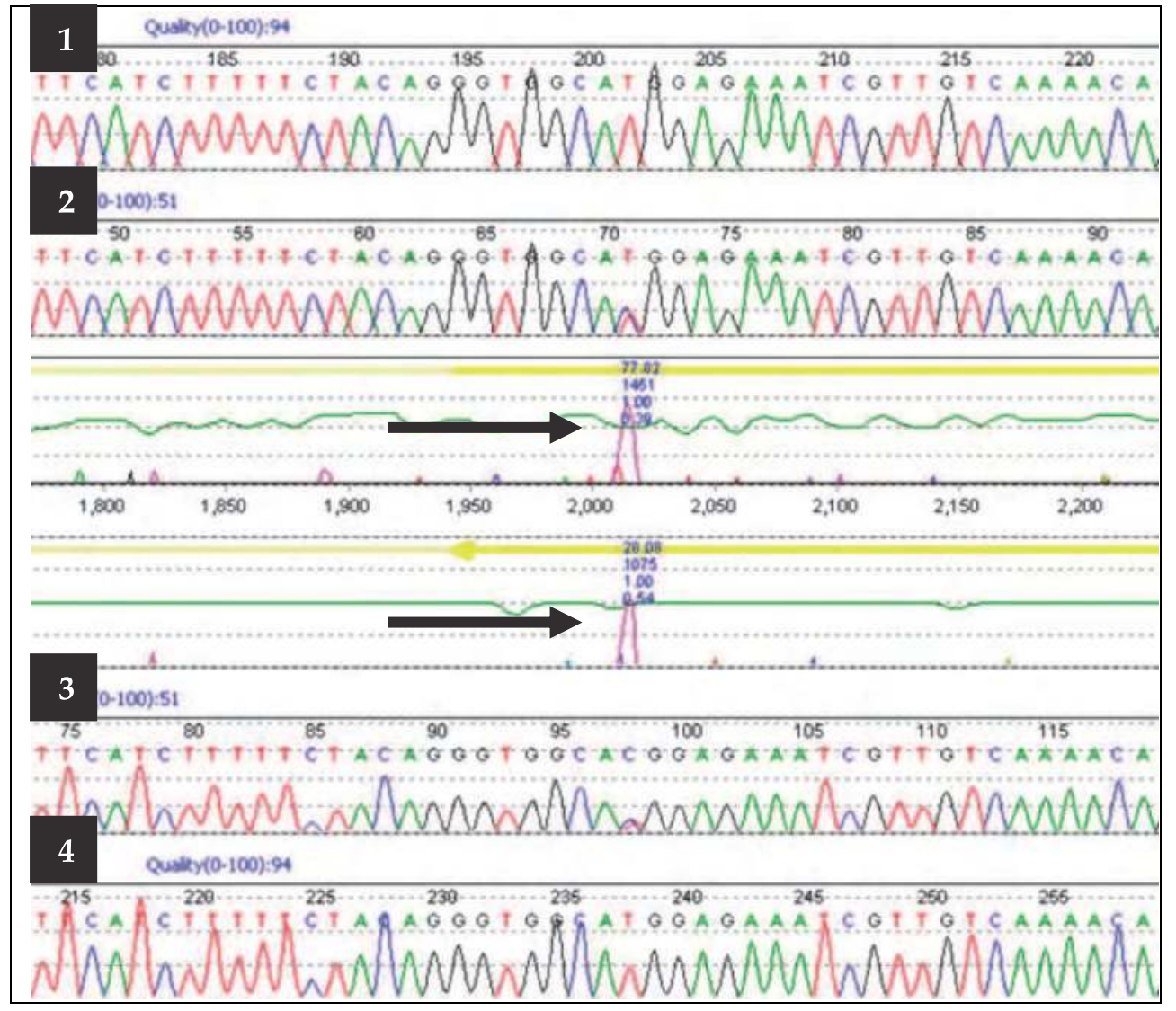

Fig. 6. Gene sequencing for lysozyme showing c. 388T>A, p. W130R, a pathogenic mutation. The top and bottom sequences ( 1 and 4$)$ are the reference sequences against which the sample is compared. Sequences 2 and 3 are the patient sample. The top trace $(1,2)$ are sequenced in the forward direction, and the bottom trace $(3,4)$ in the reverse. The two middle traces are the subtraction plots between the reference sequence and the patient sample. The intronic region is indicated by the tan line, the yellow line indicates the exon. The pink peak is the location of the mutation (arrows), indicating substitution of a cytosine for a thymine. This nucleotide substitution alters the tryptophan (W) codon TGG to CGG, which codes for arginine (R). 
the new nomenclature to derive this). Apolipoprotein A1 (ApoA1) is an example of a protein with a signal peptide and a propeptide. The signal peptide is 18 amino acids in length, and the propeptide is 6 . Hence, to extrapolate the historical nomenclature from the new nomenclature for a mutation in ApoA1, Gly50Arg would be Gly26Arg. Please refer to Table 1 for a listing of all genes and the conversions.

\begin{tabular}{|l|c|l|}
\hline Protein & Signal Peptide/Propeptide & $\begin{array}{l}\text { Example } \\
\text { (historical } \rightarrow \text { new })\end{array}$ \\
\hline TTR & 20 & Cys10Arg $\rightarrow$ Cys30Arg \\
\hline ApoA1 & $18 / 6$ & Gly26Arg $\rightarrow$ Gly50Arg \\
\hline ApoA2 & $18 / 5$ & Stop78S $\rightarrow$ Stop101S \\
\hline Gelsolin A & 27 & Asp187Tyr $\rightarrow$ Asp214Tyr \\
\hline Fibrinogen Alpha & 19 & Arg554Leu $\rightarrow$ Arg573Leu \\
\hline Lysozyme & 18 & W112R $\rightarrow$ W130R \\
\hline
\end{tabular}

Table 1. Table depicting nomenclature conversion from historical to new. The primary difference is that the new nomenclature includes all codons beginning with the initiating methionine, and the historical nomenclature utilizes only the mature protein. Hence, to convert to the new nomenclature requires adding the appropriate number of codons acting as signal peptides and propeptides, as indicated.

\subsection{Transthyretin (TTR)}

Transthyretin (TTR) was the first protein identified in hereditary amyloidosis with amyloid deposition due to coding sequence missense mutations was transthyretin. Notably, it is by far the most common protein and gene involved in familial amyloidosis, accounting for between $95-98 \%$ of reported familial amyloid cases, and often presenting after the age of 50 . TTR is a transport protein that has four exons, 127 amino acids and weighs $55 \mathrm{kDa}$, and is synthesized predominantly in the liver. The function of TTR is to carry thyroxine (T4) and to participate in the thyroxine-retinol binding protein complex. Consequently, when TTR is mutated, aberrant protein folding results with deposition as described above with the clinical sequelae including most predominantly peripheral polyneuropathy, and/or cardiomyopathy (with or without eye and brain involvement).

Due to its predominantly hepatic synthesis, liver transplantation is the treatment of choice for patients with TTR amyloidosis. Since this treatment is vastly different than the cytotoxic chemotherapeutic regimens and/or bone marrow transplant indicated for AL amyloidosis, the correct diagnosis of these two disorders with supporting laboratory data is paramount. Also, senile amyloid deposition is often composed of wild-type TTR protein. In this case, the conversion of TTR into amyloid fibrils is not driven by pathogenic mutations. Gene sequencing is necessary to distinguish TTR type senile amyloid from a hereditary disorder. Though more than 100 mutations have been reported in TTR, almost all of them are due to single base substitutions in the gene, located on chromosome 18. Common single base substitutions include V50M, L75P, L78H, T80A, and Y134H. A common threenucleotide/single codon deletion is $\Delta$ Val142. Moreover, ethnic propensities exist such as the association of V142I with African Americans. Further, M33I is seen in the German population, A45T, Y89I, and Q112K segregate amongst the Japanese. Variants common in the United States are D38N, A45S, F53C, W61L, T69P, L75Q, A101T, and R123S. Phenotypic 
clustering is seen in some codon changes (Table 2), and Tyr89lle is the only double nucleotide substitution documented to date. Specifically, Tyr89Ile is seen in the Japanese population, with cardiac and connective tissue involvement, and autonomic neuropathy.

\begin{tabular}{|l|l|l|}
\hline \multicolumn{1}{|c|}{ Mutation } & \multicolumn{1}{|c|}{ Clinical Features } & \multicolumn{1}{c|}{ Geographic kindreds } \\
\hline Phe53Ile & Peripheral Neuropathy, Eye & Israel \\
\hline Phe53Leu & Peripheral Neuropathy, Heart & USA \\
\hline Phe53Val & Peripheral Neuropathy & UK, Japan, China \\
\hline Ala65Thr & Heart & USA \\
\hline Ala65Asp & Heart, Peripheral Neuropathy & USA \\
\hline Ala65Ser & Heart & Sweden \\
\hline Ile104Asn & Heart, Eye & USA \\
\hline Ile104Thr & Heart, Peripheral Neuropathy & Germany, UK \\
\hline Glu109Gln & Peripheral Neuropathy, Heart & Italy \\
\hline Glu109Lys & Peripheral Neuropathy, Heart & USA \\
\hline Val142Ile & Heart & USA \\
\hline$\Delta$ Val142 & Heart, Peripheral Neuropathy & USA \\
\hline Val142Ala & Heart, Eye, Peripheral Neuropathy & USA \\
\hline
\end{tabular}

Table 2. Phenotypic correlations of TTR mutations along with segregation among particular geographic kindreds (adapted from Benson 2003 ).

\subsection{Apolipoprotein A1 (ApoA1)}

Apolipoprotein A1 (ApoA1), another protein involved with hereditary amyloidosis, contains four exons, 243 amino acids, weighs $28 \mathrm{kDa}$, and is located on chromosome 11q23q24. ApoA1 is synthesized in the liver and small intestine, conferring a plasma protein that is the main protein of high-density lipoprotein particles and has a key role in lipoprotein metabolism. As such, ApoA1 is important for the formation of high-density lipoprotein cholesterol esters, promoting efflux of cholesterol from cells. Mutations in ApoA1 can lead to one of two rare disease of lipoprotein metabolism, primary hypoalphalipoproteinemia or Tangier's disease; or, ApoA1 amyloidosis, depending on the mutation. Thirteen mutations are associated with ApoA1 amyloidosis, predominantly nucleotide substitutions. However, two are deletions, and one is a deletion/insertion mutation. Most of the deletionss are inframe, with the exception of Asn122fs and eAla202fs. Hence, the mechanism of amyloid production for all of the ApoA1 mutations involve aberrant folding, the unstable species produced with the Asn122fs and Ala202fs mutations is a truncated protein rather than a full length one.

The clinical presentation of amyloidosis consistent with ApoA1 involves the liver, kidney, larynx, skin and myocardium most commonly; rarely the testes and adrenal glands. The most common mutations to date include G50R, L99P, A197P, A199P, and L198S. Most of these mutations are present in Northern Europeans. Specifically, G50R is common among British, Scandinavians and North Americans, L99P in Italians, Germans, and North Americans, A197P in Americans and British, and L198S in Italian and Dutch individuals (Table 3). 


\begin{tabular}{|l|l|}
\hline Mutation & Clinical Features \\
\hline Gly50Arg & Peripheral neuropathy, Nephropathy \\
\hline Glu58_ys & Nephropathy \\
\hline Leu84Arg & Nephropathy \\
\hline Glu94_Trp96del & HTN, Nephropathy \\
\hline Trp74Arg & Nephropathy \\
\hline Del84-85insVal/Thr & Hepatic \\
\hline Leu88Pro & Nephropathy \\
\hline De194-96 & Nephropathy \\
\hline Phe95Tyr & Palate \\
\hline Asn98fs & Nephropathy, gastrointestinal \\
\hline Leu99Pro & Hepatic \\
\hline Leu114Pro & Cardiomyopathy, cutaneous \\
\hline Lys131del & Aortic intima \\
\hline Ala178fs & Nephropathy \\
\hline Leu194Pro & Laryngeal \\
\hline Arg197Pro & Cardiomyopathy, cutaneous, laryngeal \\
\hline Leu198Ser & Cardiomyopathy \\
\hline Ala199Pro & Laryngeal \\
\hline Leu202His & Cardiomyopathy, laryngeal \\
\hline
\end{tabular}

Table 3. Common ApoA1 mutations (adapted from Benson, 2003; Eriksson, et al., 2009; Rowczenio, et al., In Progress).

\subsection{Apolipoprotein A2 (ApoA2)}

Apolipoprotein A2 (ApoA2), similar to ApoA1, is an amyloidogenic protein involved with lipid metabolism. ApoA2, unlike ApoA1, can be found in senile amyloidosis. As is the case with TTR, gene sequencing is required to determine if ApoA2 deposition in a given case is due to deposition of a wild-type protein (senile amyloid) or a mutant one (familial amyloidosis). Structurally, it is a 77 amino acid, $17.4 \mathrm{kDa}$ protein located on chromosome 1p21-1qter. While comprised of four exons, three exons in ApoA2 are coding: exons 2, 3 and the $5^{\prime}$ end of exon 4 (Alamut). The Apo A2 gene is one of the more recently described forms of hereditary amyloid, with a clinical picture of early adult-onset, rapidly progressive renal failure. The abrupt renal failure occurs in the absence of proteinuria and has no associated neuropathy. Mutations in the stop codon are the common genetic change resulting in a 21amino acid extension at the carboxy terminus of the mature protein. All of these changes occur at codon 101 in exon 4 as follows: Stop101G, Stop101S, and Stop101R (Table 4). Geographically, these mutations are seen in North Americans, with the exception of Stop101R, which is also seen in Russians. 


\begin{tabular}{|l|c|l|}
\hline \multicolumn{1}{|c|}{ Protein } & Mutation & \multicolumn{1}{|c|}{ Clinical Features } \\
\hline ApoA2 & Stop78Gly & Nephropathy \\
\hline & Stop78Ser & Nephropathy \\
\hline Gelsolin A & Stop78Arg & Nephropathy \\
\hline & Asp214Asn & PN, LCD \\
\hline Fibrinogen Alpha & Asp214Tyr & PN \\
\hline & Arg573Leu & Nephropathy \\
\hline & Glu545Val & Nephropathy \\
\hline & 1629delG & Nephropathy \\
\hline Lysozyme & 1622delT & Nephropathy \\
\hline & Ile74Thr & Nephropathy, petechiae \\
\hline & Asp85His & Nephropathy \\
\hline & Trp82Arg & Nephropathy \\
\hline
\end{tabular}

Table 4. Listing of common mutation for other amyloidogenic proteins. PN = Peripheral Neuropathy, LCD = lattice corneal dystrophy.

\subsection{Gelsolin A (GSN)}

Gelsolin protein is associated with actin metabolism. Also known as brevin, or, actindepolymerizing factor, it acts to prevent toxicity due to the release of actin into the extracellular space in the presence of cell necrosis. The gene is comprised of 17 exons and is located on chromosome 9q34 (centromeric to ABL); the protein weighs $82 \mathrm{kDa}$. In the setting of familial/hereditary amyloidosis presents with unique features of neuropathy, particularly of the cranial nerves. Additionally, Gelsolin A has distinguishing clinical features that merit clinical, not genetic, subclassification of the disease. For example, some patients may have lattice corneal dystrophy, the "Meretoja" subtype, and cutis laxia of facial skin. Known pathogenic mutations include D214N in individuals from Finland, North America, Denmark and Japan, and D214Y (c. 654G>C), in individuals from Finland, Denmark, and the Czech Republic. The D214N and D214Y mutations permit exposure of an otherwise masked cleavage site, and is the initial step of amyloid formation. Both of these mutations result in the production of an aberrant, $68-\mathrm{kD}$ fragment, likely a carboxy-terminal part of the protein which is suggested to be amyloidogenic.

The Meretoja subtype is associated with the D214N mutation, a single base mutation c. 654G $>$ A (GAC $>$ GAA), p. D214N (Asp214Asn). The pathogenic protein is comprised of 71 amino acids. Individuals that are heterozygous for this mutation may be asymptomatic early in life, with possibly only lattice corneal dystrophy (in their thirties); those who are homozygous may have significant manifestations of visceral involvement, specifically renal, including proteinuria and amyloid nephropathy with nephrotic syndrome by their twenties. Regardless of the genotype, the gelsolin variant of amyloid is classically associated with cranial neuropathy, possibly even bilateral, with additional phenotypic features rendering subclassification as described herein (Table 4). 


\subsection{Fibrinogen alpha (FGA)}

Synthesized in the liver, fibrinogen is a plasma glycoprotein with three structural subunits: alpha (FGA), beta (FGB), and gamma (FGG). Most research regarding fibrinogen has been in the context of hemostasis, where it has a primary functional role. Two rare diseases due to mutations in fibrinogen alpha confer bleeding disorders: afibrinogenemia and dysfibrinogenemia. Afibrinogenemia has an absence of fibrinogen due to a truncating mutation, and dysfibrinogenemia has decreased fibrin production due to a mutation at the cleavage site for thrombin to convert inactive fibrinogen to fibrin. The mutations seen with bleeding are different than those seen in FGA amyloid. Fibrinogen alpha is located on chromosome 4q28, with 6 exons, and varying amino acid lengths as determined by alternative splicing.

Phenotypically, FGA amyloidosis is associated with visceral involvement, specifically renal, with the manifestations including hypertension, proteinuria, and subsequent azotemia. Importantly, renal involvement in amyloid of this genetic origin is associated with rapidly progressive renal failure. Hence, detection of amyloid with a FGA mutation, like TTR, permits consideration of liver transplant for curative treatment, and, perhaps, could avoid the negative consequences of renal disease. Historically, renal transplantation, which has also been performed, has not had long-term success, thus, this paradigm-shift to hepatic transplantation, especially in light of the ability to detect the mutation, is a promising alternative for patients. Neuropathy has not been seen in this type of amyloidosis, and cardiomyopathy is reported in one case, thus far. Hence, neurologic and cardiac involvement would be the exception rather than the rule at this early phase of diagnosing FGA amyloid.

To date, there are four common mutations associated with FGA amyloidosis: two point mutations with pathogenic single amino acid substitutions, and two single nucleotide deletions yielding a frameshift in DNA transcription, with subsequent premature termination of protein synthesis. One point mutation, c. 4993 G>T, p. R573L has been identified in a Peruvian family, and another, c. 1674 A>T, p. E545V has been detected in individuals of American and Irish descent. Specifically, the E545V mutation is the one example of cardiac manifestations of FGA amyloid. One mutation, 1629delG, a deletion of the third base in codon 543, was detected in an American family with hereditary renal amyloidosis. Due to this mutation, a premature stop codon is created at codon 567. Individuals with the 1629delG mutation had a later onset of disease (later thirties and early forties) when compared to those with the R573L mutation . Finally, early renal disease with terminal renal failure has been documented in French kindred with a single nucleotide deletion c.1622T, with subsequent frameshift mutation at codon 541 and, similar to $1629 \mathrm{delG}$, premature termination of protein synthesis at codon 567 (Table 4). This particular subtype, with its inherently aggressive sequelae, is particularly relevant to consideration of liver transplantation early in the course of disease.

\subsection{Lysozyme (LYZ)}

Lysozyme is an enzyme that catalyzes the hydrolysis of certain mucopolysaccharides of bacterial cell walls. Specifically, it catalyzes the hydrolysis of the beta (1-4) glycosidic linkages between $\mathrm{N}$-acetylmuramic acid and $\mathrm{N}$-acetylglucosamine. Lysozyme is found in the spleen, lung, kidney, white blood cells, plasma, saliva, milk and tears. The gene is located on chromosome 12q15 and contains 4 exons. The 14.6kDa protein contains 130 amino acids. 
In the same vein with regard to management, early detection of this amyloid variant alters the course of treatment in that individuals with this mutation experience a very early onset of renal disease, with rapid decline (this is similar, in some regards, to some variants of FGA). However, unlike FGA, benefit from renal transplantation has proven effective. Other manifestations include gastrointestinal involvement (peptic ulcer), cardiac disease, Sicca syndrome, and propensity towards petechiae, hemorrhage and hematoma, including hepatic hemorrhage. Uniquely, neuropathy is not a component of this type of amyloid, and in fact, might suggest a different variant, such as gelsolin, depending on the presentation.

The mutations documented thus far with lysozyme amyloid have their ancestral roots associated with the United Kingdom, France, America, and Italy (specifically, Piedmont, Italy). The D85H (Asp85His) mutation regionalizes to the United Kingdom, renal disease is the predominant symptom associated with this mutation. A tryptophan-to-arginine substitution at codon 82 (W82R) has been documented with a French family, with Sicca syndrome contributing to the phenotype in addition to renal manifestations. Two other mutations, Phe75Ile (F75I), and Trp82Arg (W82R), are described in an Italian-Canadian family, and an Italian family (Piedmont, Italy), respectively. The W82R variant had predominant gastrointestinal involvement; however, the same mutation in an English man presented with dramatic bleeding and rupture of abdominal lymph nodes (Table 4).

\subsection{LECT2: A new hereditary amyloidosis gene?}

The most recently described gene in systemic amyloidosis is LECT2. LECT2 is a leukocyte chemotactic factor whose synthetic origin is uncertain at this time (Benson 2010). Some studies indicate a hepatic origin as LECT2 is expressed in the adult and fetal liver, but follow-up immunohistochemical studies have detected LECT2 in many tissues of the body. LECT2 weighs $16.4 \mathrm{kDa}$, is comprised of 133 residues (after cleavage of the 18 amino acid signal peptide), and is located on chromosome $5 \mathrm{q} 31.1-\mathrm{q} 32$.

Functionally, LECT2 can serve as a cartilage growth factor (chondromodulin II), as well as in neutrophil chemotaxis, as the name implies. With its role in neutrophilic chemotaxis, LECT2 has a presumable role in cell growth and repair after damage. Further, LECT2 has also been detected in hepatocellular carcinoma cell lines, suggesting a role in neoplasia, and also supporting its potential origin within hepatic tissue.

To date, LECT2 amyloidosis has been seen primarily in individuals of Mexican American ancestry. A study by Murphy et al. reported a series of 21,985 consecutive renal biopsies, of which 285 had positive Congo Red staining. Seven of ten cases with LECT2 renal amyloidosis were of Mexican descent. In some cases (typically reported in smaller studies), the amyloid was detected after longstanding, slowly progressive renal disease.

The case reported by Benson is a patient with a long history or slowly progressive renal failure, without a diagnosis of amyloidosis including its specific subtype until nephrectomy due to renal-cell carcinoma. Moreover, since its recent discovery, there is suggestion by Larsen et al. that the incidence of LECT2 amyloid might actually exceed TTR. While a polymorphism has been detected in all of the cases affected with LECT2 amyloid (Ile58Val), no pathogenic mutations are present to date. Thus, whether or not LECT2 will emerge under the category of systemic or hereditary amyloidosis is yet to be determined. 


\section{Conclusion}

In summary, many laboratory techniques to detect and characterize the presence of amyloid are available. With these tools, the ability to detect the presence of amyloid has improved, as well as our ability to better understand the varying presentations and pathologic processes associated with the presence of amyloid.

While the understanding of amyloid continues to evolve, so does our ability to detect, diagnose, and treat the varying etiologies. Two techniques pivotal this progress are tissue mass spectrometry and gene sequencing. The refined finesse available utilizing mass spectrometry and gene sequencing continues to unravel the amyloid puzzle, and reveal more patients, with more unique phenotypic expression of disease. As our ability to identify and characterize systemic amyloidosis improves, and genotype-phenotype correlations become more clear, it will likely be possible in the future to explain seemingly unique manifestations of the disease, such as the cardiac specific presentation seen with the V142I TTR mutation.

The ultimate beneficiary of the utility of the refined laboratory diagnosis of amyloidosis is, of course, the patient. However, the information gathered due to test results is best handled in a multidisciplinary practice with well-established genetic counseling to educate the patient and family regarding the disease process, screening, and treatment considerations. At present, no direct pharmacologic therapy "cures" for the amyloid disease. However, understanding the origin of the proteins involved in the subtypes has achieved better control of this process in some types (TTR, FGA).

\section{Acknowledgments}

The authors would like to thank Steven R. Zeldenrust, MD, PhD Consultant, Division of Hematology, Mayo Clinic, Rochester, Minnesota for his critical review of the manuscript and clinical support; Jason Theis and Karen Schowalter for their assistance in the mass spectrometry and molecular genetics laboratories respectively, at Mayo Clinic, Rochester, Minnesota; Tad Holtegaard and Cindy McFarlin for their technical support, and Debbie Johnson for her administrative support; Mayo Clinic, Rochester, Minnesota.

\section{References}

Lysozyme; Lyz, In: GeneTests: Medical Genetics Information Resource (database online), 1993-2011. University of Washington, Seattle. Accessed March 10, 2011. Available from: <http://www.genetests.org>

Alamut@. Version 2.5.2011. Computer Software by Interactive Biosoftware, Rouen, France.

Fibrinogen, a Alpha Polypeptide; Fga, In: GeneTests: Medical Genetics Information Resource (database online), 1993-2011. University of Washington, Seattle. Accessed March 10, 2011. Available from: <http://www.genetests.org>

Gelsolin; Gsn, In: GeneTests: Medical Genetics Information Resource (database online), 19932011. University of Washington, Seattle. Accessed March 10, 2011. Available from: <http://www.genetests.org>

Benson, M. D., Liepnieks, J., Uemichi, T., Wheeler, G., \& Correa, R. (1993). Hereditary Renal Amyloidosis Associated with a Mutant Fibrinogen Alpha-Chain. Nature Genetics, Vol. 3, No. 3, pp. 252-255 
Benson, M. D. (2003). The Hereditary Amyloidoses. Best Practrice \& Research. Clinical Rheumatology, Vol. 17, No. 6, pp. 909-927

Benson, M. D., James, S., Scott, K., Liepnieks, J. J., \& Kluve-Beckerman, B. (2008). Leukocyte Chemotactic Factor 2: A Novel Renal Amyloid Protein. Kidney International, Vol. 74, No. 2, pp. 218-222

Benson, M. D. (2010). Lect2 Amyloidosis. Kidney International, Vol. 77, No. 9, pp. 757-759

Brill, A. K., Woelke, K., Schadlich, R., Weinz, C., \& Laier-Groeneveld, G. (2007). Tracheobronchial Amyloidosis--Bronchoscopic Diagnosis and Therapy of an Uncommon Disease: A Case Report. Journal of Physiology and Pharmacology, Vol. 58 Suppl 5, No. Pt 1, pp. 51-55

Cendron, L., Trovato, A., Seno, F., Folli, C., Alfieri, B., Zanotti, G., \& Berni, R. (2009). Amyloidogenic Potential of Transthyretin Variants: Insights from Structural and Computational Analyses. Journal of Biological Chemistry, Vol. 284, No. 38, pp. 2583225841

Coelho, T., Ericzon, B. G., Falk, R., Grogan, D. R., Ikeda, S., Maurer, M., Plante-Bordeneuve, V., Suhr, O. B., \& Trigo, P. (2008). A Physician's Guide to Transthyretin Amyloidosis. Publication from Amyloidosis Foundation, Inc., Clarkston, Michigan.

Comenzo, R. L., Zhou, P., Fleisher, M., Clark, B., \& Teruya-Feldstein, J. (2006). Seeking Confidence in the Diagnosis of Systemic Al (Ig Light-Chain) Amyloidosis: Patients Can Have Both Monoclonal Gammopathies and Hereditary Amyloid Proteins. Blood, Vol. 107, No. 9, pp. 3489-3491

Connors, L. H., Lim, A., Prokaeva, T., Roskens, V. A., \& Costello, C. E. (2003). Tabulation of Human Transthyretin (Ttr) Variants, 2003. Amyloid, Vol. 10, No. 3, pp. 160-184

Cooper, J. H. (1969). An Evaluation of Current Methods for the Diagnostic Histochemistry of Amyloid. Journal of Clinical Pathology, Vol. 22, No. 4, pp. 410-413

de la Chapelle, A., Tolvanen, R., Boysen, G., Santavy, J., Bleeker-Wagemakers, L., Maury, C. P., \& Kere, J. (1992). Gelsolin-Derived Familial Amyloidosis Caused by Asparagine or Tyrosine Substitution for Aspartic Acid at Residue 187. Nature Genetics, Vol. 2, No. 2, pp. 157-160

Eriksson, M., Schonland, S., Yumlu, S., Hegenbart, U., von Hutten, H., Gioeva, Z., Lohse, P., Buttner, J., Schmidt, H., \& Rocken, C. (2009). Hereditary Apolipoprotein AiAssociated Amyloidosis in Surgical Pathology Specimens: Identification of Three Novel Mutations in the Apoa1 Gene. Journal of Molecular Diagnostics, Vol. 11, No. 3, pp. 257-262

Fu, X., Koremaga, T., Fu, L., Xing, Y., Guo, Z., Matsushita, T., Hosokawa, M., Naiki, H., Baba, S., Kawata, Y., Ikeda, S.-i., Ishihara, T., Mori, M., \& Higuchi, K. (2004). Induction of Aapoaii Amyloidoisis by Various Heterogeneous Amyloid Fibrils. FEBS Letters, Vol. 563, No., pp. 179-184

Granel, B., Serratrice, J., Valleix, S., Grateau, G., Droz, D., Lafon, J., Sault, M. C., Chaudier, B., Disdier, P., Laugier, R., Delpech, M., \& Weiller, P. J. (2002). A Family with Gastrointestinal Amyloidosis Associated with Variant Lysozyme. Gastroenterology, Vol. 123, No. 4, pp. 1346-1349 
Granel, B., Serratrice, J., Disdier, P., Weiller, P. J., Valleix, S., Grateau, G., \& Droz, D. (2005). Underdiagnosed Amyloidosis: Amyloidosis of Lysozyme Variant. American Journal of Medicine, Vol. 118, No. 3, pp. 321-322

Hamidi Asl, L., Liepnieks, J. J., Uemichi, T., Rebibou, J. M., Justrabo, E., Droz, D., Mousson, C., Chalopin, J. M., Benson, M. D., Delpech, M., \& Grateau, G. (1997). Renal Amyloidosis with a Frame Shift Mutation in Fibrinogen Aalpha-Chain Gene Producing a Novel Amyloid Protein. Blood, Vol. 90, No. 12, pp. 4799-4805

Jacob, E., Edwards, W., Zucker, M., D'Cruz, C., Seshan, S., Crow, F., \& Highsmith, W. (2007). Homozygous Transthyretin Mutation in an African American Male. Journal of Molecular Diagnostics, Vol. 9, No. 1, pp. 127-131

Kitagawa, K., Wang, J., Mastushita, T., Kogishi, K., Hosokawa, M., Fu, X., Guo, Z., Mori, M., \& Higuchi, K. (2003). Polymorphisms of Mouse Apolipoprotein a-Ii: Seven Alleles Found among 41 Inbred Strains of Mice. Amyloid, Vol. 10, No. 4, pp. 207-214

Labro, H., Al-Kadhimi, Z., Djmil, M., Oghlakian, R., \& Alshekhlee, A. (2009). Brain Amyloidoma with Cerebral Hemorrhage. Journal of the American Osteopathic Association, Vol. 109, No. 7, pp. 372-375

Lachmann, H. J., Booth, D. R., Booth, S. E., Bybee, A., Gilbertson, J. A., Gillmore, J. D., Pepys, M. B., \& Hawkins, P. N. (2002). Misdiagnosis of Hereditary Amyloidosis as Al (Primary) Amyloidosis. New England Journal of Medicine, Vol. 346, No. 23, pp. 17861791

Lackner, K. J., Law, S. W., \& Brewer, H. B., Jr. (1985). The Human Apolipoprotein a-Ii Gene: Complete Nucleic Acid Sequence and Genomic Organization. Nucleic Acids Research, Vol. 13, No. 12, pp. 4597-4608

Larsen, C. P., Walker, P. D., Weiss, D. T., \& Solomon, A. (2010). Prevalence and Morphology of Leukocyte Chemotactic Factor 2-Associated Amyloid in Renal Biopsies. Kidney International, Vol. 77, No. 9, pp. 816-819

Lee, W. M., \& Galbraith, R. M. (1992). The Extracellular Actin-Scavenger System and Actin Toxicity. New England Journal of Medicine, Vol. 326, No. 20, pp. 1335-1341

Mainenti, P. P., Segreto, S., Mancini, M., Rispo, A., Cozzolino, I., Masone, S., Rinaldi, C. R., Nardone, G., \& Salvatore, M. (2010). Intestinal Amyloidosis: Two Cases with Different Patterns of Clinical and Imaging Presentation. World Journal of Gastroenterology, Vol. 16, No. 20, pp. 2566-2570

Maury, C. P., \& Baumann, M. (1990). Isolation and Characterization of Cardiac Amyloid in Familial Amyloid Polyneuropathy Type Iv (Finnish): Relation of the Amyloid Protein to Variant Gelsolin. Biochimica et Biophysica Acta, Vol. 1096, No. 1, pp. 84-86

Maury, C. P. (1991). Gelsolin-Related Amyloidosis. Identification of the Amyloid Protein in Finnish Hereditary Amyloidosis as a Fragment of Variant Gelsolin. Journal of Clinical Investigation, Vol. 87, No. 4, pp. 1195-1199

Meretoja, J. (1973). Genetic Aspects of Familial Amyloidosis with Corneal Lattice Dystrophy and Cranial Neuropathy. Clinical Genetics, Vol. 4, No. 3, pp. 173-185

Mourad, G., Delabre, J. P., \& Garrigue, V. (2008). Cardiac Amyloidosis with the E526v Mutation of the Fibrinogen a Alpha-Chain. New England Journal of Medicine, Vol. 359, No. 26, pp. 2847-2848 
Murphy, C. L., Eulitz, M., Hrncic, R., Sletten, K., Westermark, P., Williams, T., Macy, S. D., Wooliver, C., Wall, J., Weiss, D. T., \& Solomon, A. (2001). Chemical Typing of Amyloid Protein Contained in Formalin-Fixed Paraffin-Embedded Biopsy Specimens. American Journal of Clinical Pathology, Vol. 116, No. 1, pp. 135-142

Murphy, C. L., Wang, S., Williams, T., Weiss, D. T., \& Solomon, A. (2006). Characterization of Systemic Amyloid Deposits by Mass Spectrometry. Methods in Enzymology, Vol. 412, No., pp. 48-62

Murphy, C. L., Wang, S., Kestler, D., Larsen, C., Benson, D., Weiss, D. T., \& Solomon, A. (2010). Leukocyte Chemotactic Factor 2 (Lect2)-Associated Renal Amyloidosis: A Case Series. American Journal of Kidney Diseases, Vol. 56, No. 6, pp. 1100-1107

Paunio, T., Kangas, H., Kalkkinen, N., Haltia, M., Palo, J., \& Peltonen, L. (1994). Toward Understanding the Pathogenic Mechanisms in Gelsolin-Related Amyloidosis: In Vitro Expression Reveals an Abnormal Gelsolin Fragment. Human Molecular Genetics, Vol. 3, No. 12, pp. 2223-2229

Picken, M. M., \& Herrera, G. A. (2007). The Burden of "Sticky" Amyloid: Typing Challenges. Archives of Pathology and Laboratory Medicine, Vol. 131, No. 6, pp. 850-851

Rodriguez, F. J., Gamez, J. D., Vrana, J. A., Theis, J. D., Giannini, C., Scheithauer, B. W., Parisi, J. E., Lucchinetti, C. F., Pendlebury, W. W., Bergen, H. R., 3rd, \& Dogan, A. (2008). Immunoglobulin Derived Depositions in the Nervous System: Novel Mass Spectrometry Application for Protein Characterization in Formalin-Fixed Tissues. Laboratory Investigation, Vol. 88, No. 10, pp. 1024-1037

Rowczenio, D., Dogan, A., Theis, J., Vrana, J., Lachmann, H., Wechalekar, A., Gilbertson, J., Hunt, T., Gibbs, S., Sattianayagam, P., Pinney, J., Hawkins, P., \& Gillmore, J. (In Progress). Five Novel Mutations of the Apolipoprotein a-I Gene with Variable Amyloidogenicity and Clinical Phenotype.

Solomon, A., Murphy, C. L., \& Westermark, P. (2008). Unreliability of Immunohistochemistry for Typing Amyloid Deposits. Archives of Pathology and Laboratory Medicine, Vol. 132, No. 1, pp. 14; author reply 14-15

Uemichi, T., Liepnieks, J. J., \& Benson, M. D. (1994). Hereditary Renal Amyloidosis with a Novel Variant Fibrinogen. Journal of Clinical Investigation, Vol. 93, No. 2, pp. 731736

Uemichi, T., Liepnieks, J. J., Alexander, F., \& Benson, M. D. (1996). The Molecular Basis of Renal Amyloidosis in Irish-American and Polish-Canadian Kindreds. Quarterly Journal of Medicine, Vol. 89, No. 10, pp. 745-750

Uemichi, T., Liepnieks, J. J., Yamada, T., Gertz, M. A., Bang, N., \& Benson, M. D. (1996). A Frame Shift Mutation in the Fibrinogen a Alpha Chain Gene in a Kindred with Renal Amyloidosis. Blood, Vol. 87, No. 10, pp. 4197-4203

Vrana, J. A., Gamez, J. D., Madden, B. J., Theis, J. D., Bergen, H. R., 3rd, \& Dogan, A. (2009). Classification of Amyloidosis by Laser Microdissection and Mass SpectrometryBased Proteomic Analysis in Clinical Biopsy Specimens. Blood, Vol. 114, No. 24, pp. 4957-4959 
Yamagoe, S., Kameoka, Y., Hashimoto, K., Mizuno, S., \& Suzuki, K. (1998). Molecular Cloning, Structural Characterization, and Chromosomal Mapping of the Human Lect2 Gene. Genomics, Vol. 48, No. 3, pp. 324-329

Yazaki, M., Liepnieks, J. J., Barats, M. S., Cohen, A. H., \& Benson, M. D. (2003). Hereditary Systemic Amyloidosis Associated with a New Apolipoprotein Aii Stop Codon Mutation Stop78arg. Kidney International, Vol. 64, No. 1, pp. 11-16 


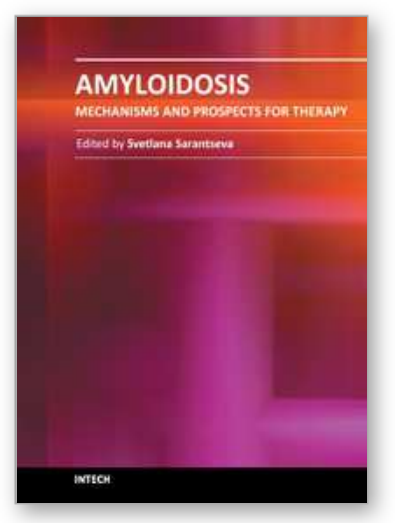

\author{
Amyloidosis - Mechanisms and Prospects for Therapy \\ Edited by Dr. Svetlana Sarantseva
}

ISBN 978-953-307-253-1

Hard cover, 216 pages

Publisher InTech

Published online 22, September, 2011

Published in print edition September, 2011

Amyloidoses are a heterogeneous group of diverse etiology diseases. They are characterized by an endogenous production of abnormal proteins called amyloid proteins, which are not hydrosoluble, form depots in various organs and tissue of animals and humans and cause dysfunctions. Despite many decades of research, the origin of the pathogenesis and the molecular determinants involved in amyloid diseases has remained elusive. At present, there is not an effective treatment to prevent protein misfolding in these amyloid diseases. The aim of this book is to present an overview of different aspects of amyloidoses from basic mechanisms and diagnosis to latest advancements in treatment.

\title{
How to reference
}

In order to correctly reference this scholarly work, feel free to copy and paste the following:

S. Michelle Shiller, Ahmet Dogan and W. Edward Highsmith, Jr. (2011). Laboratory Methods for the Diagnosis of Hereditary Amyloidoses, Amyloidosis - Mechanisms and Prospects for Therapy, Dr. Svetlana Sarantseva (Ed.), ISBN: 978-953-307-253-1, InTech, Available from: http://www.intechopen.com/books/amyloidosismechanisms-and-prospects-for-therapy/laboratory-methods-for-the-diagnosis-of-hereditary-amyloidoses

\section{INTECH}

open science | open minds

\section{InTech Europe}

University Campus STeP Ri Slavka Krautzeka 83/A 51000 Rijeka, Croatia

Phone: +385 (51) 770447

Fax: +385 (51) 686166 www.intechopen.com

\section{InTech China}

Unit 405, Office Block, Hotel Equatorial Shanghai

No.65, Yan An Road (West), Shanghai, 200040, China 中国上海市延安西路65号上海国际贵都大饭店办公楼 405 单元 Phone: +86-21-62489820

Fax: +86-21-62489821 
(C) 2011 The Author(s). Licensee IntechOpen. This chapter is distributed under the terms of the Creative Commons Attribution-NonCommercialShareAlike-3.0 License, which permits use, distribution and reproduction for non-commercial purposes, provided the original is properly cited and derivative works building on this content are distributed under the same license. 